\title{
Analisis Peran Stakeholders Dalam Pengembangan Destinasi Pariwisata Halal Di Pulau Penyengat Provinsi Kepulauan Riau
}

\author{
Riska Destiana1, Kismartini ${ }^{2}$, Tri Yuningsih ${ }^{3}$ \\ ${ }^{1}$ Mahasiswa Magister Administrasi Publik, Fakultas Ilmu Sosial dan Ilmu Politik Universitas \\ Diponegoro, Jl .ImamBardjo SH No.3-5 Semarang \\ ${ }^{23}$ Dosen Departemen Administrasi Publik, Fakultas Ilmu Sosial dan Ilmu Politik Universitas \\ Diponegoro, Jl .Imam Bardjo SH No.3-5 Semarang
}

\begin{abstract}
Pulau Penyengat is designated as a leading area for halal tourism development. The development of halal tourism on Pulau Penyengat requires cooperation and support from many parties. The less optimal role of stakeholders in tourism development cooperation makes the reason for the importance of this research being carried out. The purpose of this research is to identify the stakeholders involved, analyze the roles of stakeholders, analyze the relationships between stakeholders, and analyze supporting and inhibiting factors. The method uses a qualitative descriptive approach, with data collection techniques combining online interviews, documentation and observations. The results show that the development of the island's halal tourism destinations involves stakeholders with the pentahelix concept, consisting of academics, business, community, government and mass media. There are 38 stakeholders involved and classified into primary, key and secondary stakeholders. The role of stakeholders is reflected in the roles of policy creators, coordinators, facilitators, implementers and accelerators. The relationship between stakeholders is seen from the form and activities. Value and communication are supporting factors in the development of halal tourism destinations, and trust and policies are inhibiting factors. The suggestions conveyed are the issuance of halal tourism regulations, the formation of a special tourism agency for Pulau Penyengat, increased coordination between stakeholders, increasing the role of academic and community stakeholders, improving halal tourism support facilities, and promoting halal tourism through digital channels.
\end{abstract}

Keywords: Halal tourism, Stakeholders, Tourism Development

\begin{abstract}
Abstrak
Pulau Penyengat ditunjuk sebagai kawasan unggulan pengembangan pariwisata halal. Pengembangan pariwisata halal di Pulau Penyengat membutuhkan kerjasama dan dukungan dari banyak pihak. Kurang optimalnya peran stakeholders dalam kerjasama pengembangan pariwisata menjadikan alasan pentingnya penelitian ini dilakukan. Tujuan penelitian ini untuk mengidentifikasi stakeholders yang terlibat, menganalisis peran stakeholders, menganalisis hubungan antar stakeholders, dan menganalisis faktor pendukung dan penghambat. Metode menggunakan pendekatan deskriptif kualitatif, dengan teknik pengumpulan data menggabungkan wawancara secara daring, dokumentasi dan observasi.Hasil penelitian menunjukkan bahwa pengembangan destinasi pariwisata halal Pulau Penyengat melibatkan stakeholders dengan konsep pentahelix, terdiri dari akademisi, bisnis, komunitas, pemerintah dan media massa. Terdapat 38 stakeholders yang terlibat dan diklasifikasikan ke dalam stakeholders primer, kunci dan sekunder. Peran stakeholders tercermin dalam peran policy creator, koordinator, fasilitator, implementor dan akselerator. Hubungan antar stakeholders dilihat dari bentuk dan aktivitasnya. Nilai dan komunikasi menjadi faktor pendukung dalam pengembangan destinasi pariwisata halal, serta kepercayaan dan kebijakan menjadi faktor penghambatnya. Saran yang disampaikan adalah penerbitan regulasi
\end{abstract}


pariwisata halal, pembentukan badan khusus wisata Pulau Penyengat, peningkatan koordinasi antar stakeholders, peningkatan peran stakeholders akademisi dan komunitas, perbaikan fasilitas pendukung pariwisata halal, dan promosi pariwisata halal melalui saluran digital.

Kata Kunci : Pariwisata halal,Stakeholders, Pengembangan Pariwisata

*)Penulis Korespondensi

E-mail : destiana.riska1812@gmail.com

\section{PENDAHULUAN}

Dikutip

dari

www.kemenpar.go.id, Kementerian Pariwisata melaporkan penetapan Indonesia berdasarkan Global Muslim Travel Index (GMTI) 2019 menjadi tujuan wisata halal terbaik dunia di 2019. Pulau Penyengat menjadi salah satu kawasan unggulan wisata halal yang tercantum dalam Design Strategis dan Rencana Aksi (DSRA) Pengembangan Destinasi Pariwisata Halal di Provinsi Kepulauan Riau 2018-2019. Pulau Penyengat, yang terletak di wilayah administrasi Pemerintah Kota Tanjungpinang, dipilih menjadi salah satu destinasi unggulan dikarenakan kekayaan budayanya. Kementerian Pariwisata telah menunjuk Pulau Penyengat menjadi pilot project destinasi wisata halal di Kepulauan Riau dan dianggap dapat mendorong percepatan pengembangan pariwisata halal dengan kelebihan letak Kepulauan Riau yang strategis sebagai pintu masuk wisatawan mancanegara (https://www.indonesiatravel.news/ pariwisata/pulau-penyengat-jadipilot-project-wisata-halal/).

Alonso (2015) menyatakan bahwa pengembangan pariwisata yang berkelanjutan erat hubungannya dengan keterlibatan stakeholders. Penguatan peran stakeholders dalam pengembangan pariwisata memberikan dampak jangka panjang dalam aspek ekonomi, ekologi dan sosial kultural (Firdaus, 2015). Keterlibatan peran stakeholders menghasilkan perencanaan strategi pariwisata yang diterima dengan baik, menghindari konflik yang timbul selama implementasi kebijakan dan menyatukan mereka yang secara langsung dan tidak langsung terlibat dalam pariwisata (Wanner, 2019). Hubungan dan koordinasi berbagai peran stakeholders dalam suatu destinasi membentuk produk wisata yang berkualitas dan citra destinasi yang mudah dikenali, mencapai keunggulan dan daya saing jangka panjang, serta pengembangan destinasi wisata yang berkelanjutan (Miočić, 2016). Dengan beberapa alasan itulah peran stakeholders dianggap penting dalam pengembangan pariwisata, karena selain menghasilkan perencanaan strategi pariwisata yang merepresentasikan banyak kepentingan, peran stakeholders juga dapat menciptakan sistem pengelolaan pariwisata yang efektif dan mewujudkan pariwisata yang berkelanjutan.

Pulau Penyengat sebagai kawasan wisata masih menghadapi masalah mengenai sarana dan prasarana, khususnya dalam pelaksanaan konsep pariwisata halal. Persoalan mengenai minimnya sarana dan parasarana pendukung pariwisata di Pulau Penyengat 
disinggung dalam sejumlah penelitian, dan disimpulkan menjadi salah satu kendala dalam pengembangan pariwisata di Pulau Penyengat (Ismandianto et al, 2019; Persari et al, 2018; Zahra, 2019). Dan informasi dari laman haluankepri.com, diketahui bahwa hanya 60 produsen kelompok usaha rumah makan dan kue yang memiliki sertifikat halal terhitung 17 Juni 2019. Pemerintah Kota Tanjungpinang sampai saat ini juga belum menerbitkan regulasi mengenai pariwisata halal di Pulau Penyengat. Judissseno (2017) menyebutkan bahwa pemerintah harus menetapkan kerangka kebijakan pembangunan pariwisata agar pihak swasta memiliki pijakan dan landasan jika ingin berpartisipasi dalam pembangunan pariwisata.

Pemerintah setempat tampaknya juga masih belum sepenuhnya melibatkan masyarakat dalam proses pengambilan kebijakan pengembangan pariwisata, sehingga masyarakat menganggap aspirasi mereka kurang diperhatikan (Zahra (2019). Perbedaan kepentingan antara pemerintah dengan masyarakat setempat dalam pengelolaan pariwisata disinyalir sebagai penyebab bentuk pengelolaan pariwisata yang tidak menjaring aspirasi dari masyarakat serta kurang melihat potensi keterlibatan masyarakat di destinasi wisata (Yulianty, 2005). Hambatan lain dalam pengembangan pariwisata Pulau Penyengat adalah komunikasi antar pemerintah dan pengelola belum maksimal. Model komunikasi pemerintahan dalam pengembangan pariwisata Pulau Penyengat belum melibatkan semua unsur terkait (Ismandianto, 2019). Pangestoeti (2016) dan Persari (2018) menemukan bahwa implementasi kebijakan mengenai destinasi pariwisata di Pulau Penyengat belum optimal, dikarenakan masih adanya faktor penghambat seperti belum optimal sinergitas dan kemitraan. Belum optimalnya proses koordinasi yang terjadi di antara seluruh instansi terkait mengakibatkan pelaksanaan kegiatan pelestarian yang belum terarah dengan baik.

Dari beberapa penelitian yang disebutkan di atas pengembangan pariwisata di Pulau Penyengat memiliki hambatan dalam aspek peran dan kerjasama para pihak terkait yang selama ini kurang koordinasi dan sinergitas, sehingga tujuan pengelolaan objek wisata belum bisa berjalan searah dan mendapatkan hasil yang maksimal dalam peningkatan citra serta angka kunjungan wisatawan. Selain fasilitas pendukung pariwisata yang masih belum dapat dikatakan layak dan baik, partisipasi masyarakat dalam kegiatan kepariwisataan juga masih rendah. Pengembangan destinasi pariwisata halal membutuhkan kerjasama antar seluruh stakeholders yang terkait. Melihat fenomena di atas, bahwa masalah penelitian berupa peran stakeholders yang terlibat dalam pengembangan destinasi pariwisata halal di Pulau Penyengat Provinsi Kepulauan Riau belum optimal, sehingga penelitian ini menjawab pertanyaan sebagai berikut:

a. Siapa yang menjadi stakeholders dalam pengembangan destinasi pariwisata halal di Pulau Penyengat Provinsi Kepulauan Riau?

b. Bagaimana peran stakeholders yang terlibat dalam pengembangan destinasi pariwisata halal di Pulau Penyengat Provinsi Kepulauan Riau?

c. Bagaimana hubungan antara stakeholders yang terlibat dalam 
pengembangan destinasi pariwisata halal di Pulau Penyengat Provinsi Kepulauan Riau?

d. Faktor-faktor apa yang mendukung dan menghambat peran stakeholders yang terlibat dalam pengembangan destinasi pariwisata halal di Pulau Penyengat Provinsi Kepulauan Riau?

\section{METODE PENELITIAN}

Penelitian ini menggunakan metode penelitian deskriptif kualitatif. Pemilihan Pulau Penyengat sebagai lokasi penelitian karena Pulau Penyengat ditunjuk oleh Kementerian Pariwisata menjadi salah satu destinasi wisata unggulan dan pilot project pengembangan pariwisata halal di Provinsi Kepulauan Riau. Data yang digunakan adalah data primer (data dari informan) dan data sekunder (bukubuku pustaka, catatan-catatan ilmiah, jurnal ilmiah serta laporan, arsip atau dokumen lainnya). Penentuan Informan menggunakan teknik purposive dan teknik snowball. Pengumpulan data dilakukan dengan cara wawancara secara daring dan/atau telepon, dokumentasi dan observasi). Penelitian ini menggunakan model analisis data dari Miles dan Huberman (dalam Sugiyono, 2011), yaitu analisis interaktif dengan langkah-langkah reduksi data, penyajian data dan menarik kesimpulan. Validitas data menggunakan teknik triangulasi sumber, yaitu mengumpulkan data sejenis dari beberapa sumber data yang berbeda (Moleong, 2017).

\section{HASIL DAN DISKUSI/ANALISIS}

Berdasarkan

letak geografisnya Pulau Penyengat relatif dekat dengan Kota Tanjungpinang sebagai pintu gerbang pariwisata
Pulau Penyengat, hanya berjarak 2 km dari Kota Tanjungpinang, Provinsi Kepulauan Riau. Secara administratif, Pulau Penyengat merupakan salah satu kelurahan di Kecamatan Tanjungpinang Kota. Memiliki luas lahan 94 hektar, Pulau Penyengat terbagi menjadi enam kampung yaitu Kampung Jambat, Kampung Balik Kota, Kampung Datuk, Kampung Baru, Kampung Bulang dan Kampung Ladi. Pulau Penyengat merupakan wilayah pengembangan wisata yang berbasis wisata budaya dan wisata religi. Pulau Penyengat memiliki berbagai macam peninggalan bersejarah antara lain makammakam para raja seperti Raja Ali Haji, Mesjid Raya Sultan Riau yang terbuat dari putih telur sebagai perekat bangunan dan benteng pertahanan di Bukit Kursi. Pariwisata Pulau Penyengat yang mengangkat wisata budaya didukung dengan Keputusan Menteri Pendidikan dan Kebudayaan Nomor 112/M/2018 tentang Kawasan Cagar Budaya Pulau Penyengat Sebagai Kawasan Cagar Budaya Peringkat Nasional. Pengembangan wisata budaya juga diperkuat dengan Peraturan Daerah Kota Tanjungpinang Nomor 8 Tahun 2018 tentang Pengelolaan Wisata Budaya Pulau Penyengat.

\section{Identifikasi Stakeholders Model Pentahelix}

Stakeholders dalam pengembangan destinasi pariwisata halal di Pulau Penyengat Provinsi Kepulauan Riau dilihat berdasarkan model pentahelix terdiri dari:

1. Akademisi

Sekolah Tinggi Ilmu Sosial dan Ilmu Politik (Stisipol) Raja Haji, Universitas Maritim Raja Ali Haji (UMRAH) dan Universitas Gajah Mada (UGM).

2. Bisnis

Perhimpunan Hotel dan Restoran Indonesia (PHRI) Tanjungpinang, 
Association of the Indonesian Tours and Travel Agencies (ASITA) Tanjungpinang, Himpunan Pramuwisata Indonesia (HPI) Tanjungpinang, Asosiasi Kuliner Rumahan, Bank Indonesia, PT. Pelabuhan Indonesia I (Pelindo 1) dan Al Ahmadi Enterprenuership Center Batam.

3. Pemerintah

Dinas Kebudayaan dan Pariwisata Kota Tanjungpinang, Dinas Perdagangan dan Perindustrian Kota Tanjungpinang, Dinas Koperasi dan UMKM Kota Tanjungpinang, Dinas Kesehatan Kota Tanjungpinang, Dinas Perhubungan Kota Tanjungpinang, Dinas Pekerjaan Umum dan Penataan Ruang Kota Tanjungpinang, Badan Perencanaan, Penelitian dan Pengembangan Kota Tanjungpinang, Satuan Polisi Pamong Praja dan Penanggulangan Kebakaran Kota Tanjungpinang, Dinas Perhubungan Provinsi Kepulauan Riau, Kementerian Agama Kantor Wilayah Provinsi Kepulauan Riau, dan Dewan Perwakilan Rakyat Daerah Kota Tanjungpinang.

4. Komunitas

Kelompok Sadar Wisata (Pokdarwis) Pulau Penyengat, Majelis Ulama Indonesia (MUI) Kepulauan Riau, Lembaga Pengkajian Pangan, Obat-obatan dan Kosmetika Majelis Ulama Indonesia (LPPOM MUI) Kepulauan Riau, Lembaga Adat Melayu (LAM) Provinsi Kepulauan Riau, Yayasan Indera Sakti, Yayasan Aksi Bangun Negeri, Komunitas Blogger, Komunitas Fotografi, dan Generasi Pesona Indonesia (Genpi) Tanjungpinang.
5. Media massa

Radio Republik Indonesia (RRI) Tanjungpinang, Batam Pos, Tanjungpinang Pos, Tribun Batam, Antara Kepri, Metro Kepri, TV TPI, dan Kepri Cyber School (KCS) TV.

Stakeholders yang terlibat dalam pengembangan destinasi pariwisata halal di Pulau Penyengat terdiri dari lima elemen, yaitu Akademisi, Bisnis, Pemerintah, Komunitas dan Media Massa. Hal ini sejalan dengan hasil penelitian oleh Yuniningsih (2018) yang menyimpulkan bahwa model kemitraan kebijakan pengembangan pariwisata di Kota Tanjungpinang dikategorikan menggunakan model Pentahelix, karena melibatkan lima elemen yaitu: Akademisi, Bisnis, Community, Government dan Media Massa (ABCGM). Pulau Penyengat merupakan salah satu kelurahan di Kota Tanjungpinang, sehingga terdapat kesamaan model pelibatan lima elemen aktor dalam pengembangan pariwisata.

\section{Kategori Stakeholders}

\section{Stakeholders Primer}

Dinas Kebudayaan dan Pariwisata Kota Tanjungpinang sebagai leading sector pengembangan destinasi pariwisata halal di Pulau Penyengat termasuk dalam stakeholders primer karena dampak dari penerapan kebijakan pengembangan pariwisata halal akan dirasakan sebagai bentuk pelaksanaan fungsi implementasi kebijakan pariwisata. Dinas Kebudayaan dan Pariwisata Kota Tanjungpinang harus selalu dilibatkan dalam setiap tahapan kebijakan pariwisata halal karena memiliki kekuatan yang besar untuk mengakses berbagai sumberdaya yang diperlukan dalam pengembangan pariwisata 
halal. Dalam proyek pariwisata berkelanjutan dengan beberapa stakeholders, ditemukan bahwa stakeholders dengan akses ke sumber daya adalah pusat dalam pengembangan proyek dengan kekuatan dan legitimasi tertinggi (Longart, 2017).

2. Stakeholders Kunci

$\begin{array}{cc}\text { Stakeholders } & \text { kunci di } \\ \text { dalam tahap } & \text { perumusan }\end{array}$
kebijakan adalah pihak Eksekutif yang diwakili Walikota Tanjungpinang dan pihak Legislatif yang diwakili DPRD Kota Tanjungpinang. Dan yang menjadi stakeholders kunci pada tahap implementasi kebijakan adalah Dinas Kebudayaan dan Pariwisata Kota Tanjungpinang. Stakeholders kunci meliputi cabang eksekutif pemerintah sesuai dengan hierarki, cabang legislatif, dan lembaga pelaksana program pembangunan (Putera and Suharto dalam Sari, 2017). Dengan kewenangan legal dalam pengambilan keputusan, Walikota Tanjungpinang dan DPRD Kota Tanjungpinang harus memiliki kepemimpinan kuat. Longart (2017) menemukan bahwa program dengan berbagai stakeholders, yang tujuan dan perannya sangat berbeda, membutuhkan kepemimpinan yang lebih kuat dan manajemen stakeholders. Semua stakeholders harus diinformasikan tentang peran dan keterlibatan stakeholders lainnya. Ini karena legitimasi dapat dipertanyakan atau peran stakeholders yang berpartisipasi lainnya dapat diabaikan. Weerts dan Sandmann (dalam Longart, 2017) menemukan bahwa kepemimpinan yang kuat adalah faktor kunci untuk keterlibatan masyarakat.
3. Stakeholders Sekunder

Badan Perencanaan, Penelitian dan Pengembangan Kota Tanjungpinang, Kementerian Agama Kantor Wilayah Provinsi Kepulauan Riau, MUI Kepulauan Riau, LPPOM MUI Kepulauan Riau, Dinas Perdagangan dan Perindustrian Kota Tanjungpinang, Dinas Koperasi dan UMKM Kota Tanjungpinang, Dinas Kesehatan Kota Tanjungpinang, Dinas Perhubungan Kota Tanjungpinang, Dinas Pekerjaan Umum dan Penataan Ruang Kota Tanjungpinang, Satuan Polisi Pamong Praja dan Penanggulangan Kebakaran Kota Tanjungpinang, Dinas Perhubungan Provinsi Kepulauan Riau, Pokdarwis Pulau Penyengat, PHRI Tanjungpinang, ASITA Tanjungpinang, HPI Tanjungpinang, Asosiasi Kuliner Rumahan, Stisipol Raja Haji, UMRAH, UGM, Bank Indonesia, Pelindo 1, Al Ahmadi Enterprenuership Center Batam, LAM Provinsi Kepulauan Riau, Yayasan Indera Sakti, Yayasan Aksi Bangun Negeri, Komunitas Blogger, Komunitas Fotografi, Genpi Tanjungpinang, RRI Tanjungpinang, Batam Pos, Tanjungpinang Pos, Tribun Batam, Antara Kepri, Metro Kepri, TV TPI, dan KCS TV.

Kelompok kritik, LSM profesional, organisasi sosial, dan lembaga keuangan internasional dikategorikan sebagai pemangku kepentingan sekunder (Putera and Suharto dalam Sari, 2017). Crosby (dalam Iqbal, 2007) menyatakan ada beberapa faktor yang dapat dijadikan acuan dalam menilai pengaruh stakeholders sekunder, yaitu : anggaran dan pengawasan; kekuasaan dan 
kepemimpinan; pengawasan terhadap sumber daya strategis; keberadaan tenaga-tenaga spesialis; dan kemampuan negosiasi. Stakeholders perlu dilibatkan untuk meningkatkan kualitas dan efektivitas kebijakan melalui pengetahuan mereka, dengan demikian komunikasi yang kuat antara stakeholders dan otoritas setempat diperlukan (Olovsson, 2012).

\section{Peran Stakeholders}

\section{a. Policy Creator}

Pengembangan pariwisata halal di Kota Tanjungpinang belum didukung dengan terbitnya regulasi yang mengatur penyelenggaraan segmen pariwisata halal. Sebagai dampak dari Kementerian Pariwisata yang juga belum menerbitkan regulasi yang mengatur proses pengembangan pariwisata halal, sehingga proses pengembangan pariwisata halal selama ini di Kota Tanjungpinang mengacu pada DSRA Pengembangan Destinasi Pariwisata Halal Kepulauan Riau yang telah disepakati sebelumnya melalui FGD. Walikota Tanjungpinang, DPRD Kota Tanjungpinang, Dinas Kebudayaan dan Pariwisata Kota Tanjungpinang dan Badan Perencanaan, Penelitian dan Pengembangan (Barenlitbang) Kota Tanjungpinang merupakan stakeholders yang terlibat dalam pengembangan pariwisata halal Pulau Penyengat yang berperan sebagai policy creator. Belum diterbitkannya regulasi pengembangan destinasi pariwisata halal Pulau Penyengat mengindikasikan bahwa peran Walikota Tanjungpinang sebagai policy creator belum dilaksanakan secara optimal. Berdasarkan uraian di atas dapat dilihat bahwa peran stakeholders sebagai policy creator belum berjalan secara maksimal. Regulasi pengembangan pariwisata halal yang memuat prinsip-prinsip penyelenggaraan pariwisata halal secara terperinci akan menjadi acuan dan payung hukum yang kuat untuk pelaku industri wisata menerapkan konsep wisata halal ini. Brokaj (2014) menyatakan bahwa pemerintah daerah harus menyediakan lingkungan yang memungkinkan dan mendorong sektor swasta, masyarakat lokal, wisatawan, dan stakeholders lainnya untuk menanggapi masalah pariwisata secara berkelanjutan. Hal ini dapat dicapai dengan menetapkan dan menerapkan serangkaian kebijakan untuk pengembangan dan pengelolaan pariwisata, disusun bersama dengan pihak lain. Prinsipprinsip pembangunan berkelanjutan menekankan pada tekad lokal dan implementasi kebijakan dan tindakan. Keberlanjutan harus diupayakan melalui adopsi kebijakan pariwisata, mengingat pentingnya sektor publik (di tingkat negara bagian, regional dan kota) dalam pengembangan pariwisata (Martini, 2015). Manajemen pariwisata dengan demikian harus diintegrasikan ke dalam proses perencanaan wilayah dan dimasukkan dalam kerangka legislatif suatu wilayah.

\section{b. Koordinator}

Stakeholders

yang menjalankan perannya sebagai koordinator dalam pengembangan destinasi pariwisata halal di Pulau Penyengat adalah Dinas Kebudayaan dan Pariwisata Kota Tanjungpinang. Upaya koordinasi stakeholders yang terlibat dilakukan melalui pertemuan yang mengundang stakeholders dari pihak pemerintah, bisnis dan asosiasi/komunitas. Dalam pertemuan tersebut dipaparkan rencana pengembangan pariwisata halal Tanjungpinang yang menjadikan Pulau Penyengat menjadi 
destinasi wisata halal unggulan dengan potensi wisata budaya, religi dan sejarahnya. Koordinasi dengan stakeholders pariwisata halal dilanjutkan melalui forum pertemuan setiap tiga bulan sekali, dan komunikasi informal yang banyak dilakukan melalui grup Whatsapp. Peran Dinas Kebudayaan dan Pariwisata Kota Tanjungpinang sebagai koordinator dalam pengembangan destinasi pariwisata halal di Pulau Penyengat belum berjalan secara optimal. Koordinasi terhadap seluruh pemangku kepentingan pengembangan destinasi pariwisata halal di Pulau Penyengat belum dilaksanakan secara menyeluruh karena terdapat stakeholders yang belum menjalin kerjasama dan komunikasi, serta belum adanya penyatuan komitmen secara tertulis agar kerjasama yang dilakukan berjalan sesuai dengan hak dan kewajiban. Judisseno (2017) menjelaskan bahwa koordinator bidang pariwisata dituntut untuk memiliki kemampuan sebagai berikut:

1. Having a global picture, yaitu kemampuan untuk memahami visi jangka panjang dari semua elemen yang dipimpinnya

2. Setting a common goal, yaitu kemampuan untuk memilah mana di antara elemen tersebut yang dapat dijadikan roda penggerak utama yang dapat memicu pergerakan lainnya.

3. Knowing your team and defining team roles, yaitu kemampuan untuk mengetahui kekuatan spesifik dari masing-masing elemen di dalam menjalankan tugasnya.

4. Planning, yaitu kemampuan menyusun tugas pokok dan fungsi elemen lengkap dengan alokasi waktu, biaya, dan target capaian yang perlu ditinjau ulang secara berkala

5. Communicating and disseminating, yaitu kemampuan untuk mengkomunikasikan dan menyebarkan semua program yang sudah disusun menjadi suatu aksi yang dapat dilakukan oleh semua elemen tanpa keraguan.

6. Reviewing and controlling, yaitu kemampuan untuk mengendalikan pelaksanaan kegiatan jika terjadi suatu hal di luar perencanaan dengan mempersiapkan skenario pilihan.

\section{c. Fasilitator}

Stakeholders yang terlibat dalam pengembangan destinasi pariwisata halal Pulau Penyengat dan berperan sebagai fasilitator adalah Dinas Kebudayaan dan Pariwisata Kota Tanjungpinang, Dinas Perdagangan dan Perindustrian Kota Tanjungpinang, Dinas Koperasi dan UMKM Kota Tanjungpinang, Dinas Kesehatan Kota Tanjungpinang, Dinas Perhubungan Kota Tanjungpinang, Dinas Pekerjaan Umum dan Penataan Ruang Kota Tanjungpinang, Satuan Polisi Pamong Praja dan Penanggulangan Kebakaran Kota Tanjungpinang, Dinas Perhubungan Provinsi Kepulauan Riau, Kementerian Agama Kantor Wilayah Provinsi Kepulauan Riau, MUI Kepulauan Riau, LPPOM MUI Kepulauan Riau. Pengembangan dari aspek fasilitas umum yang ramah wisatawan Muslim dilakukan oleh Dinas Kebudayaan dan Pariwisata Kota Tanjungpinang. Melalui Dana Alokasi Khusus (DAK) tahun 2019, Dinas Kebudayaan dan Pariwisata Kota Tanjungpinang telah menyelesaikan pembangunan mushola di Balai Adat Pulau Penyengat, food court makanan halal, dan pusat oleh-oleh di Pulau Penyengat. Dinas Perhubungan Kota 
Tanjungpinang dan Dinas Perhubungan Provinsi Kepulauan Riau menjadi stakeholders yang berperan sebagai fasilitator dalam penyediaan akses menuju Pulau Penyengat. Peran Dinas Pekerjaan Umum dan Penataan Ruang Kota Tanjungpinang dalam mendukung pengembangan pariwisata halal di Pulau Penyengat dapat dilihat dari penyediaan air bersih dan pembuatan Rencana Tata Bangunan dan Lingkungan (RTBL) Pulau Penyengat. Dinas Kesehatan Kota Tanjungpinang sangat membantu para pengusaha kuliner di Pulau Penyengat yang akan memproses sertifikat BPOM untuk penjaminan keamanan dan mutu produk yang mereka hasilkan. Dinas Perdagangan dan Perindustrian Kota Tanjungpinang, bekerjasama sama dengan Kementerian Agama dan LPPOM MUI, memiliki program kerja tahunan pemberian fasilitasi proses sertifikat halal bagi UMKM. Pembinaan UMKM oleh Dinas Koperasi dan UMKM Kota Tanjungpinang dapat dilihat dari aspek pembinaan manajemen, pengembangan pasar produk UMKM serta fasilitasi modal usaha. Peran Satuan Polisi Pamong Praja dan Penanggulangan Kebakaran Kota Tanjungpinang dijalankan melalui satuan tugas khusus pariwisata yang belum lama terbentuk, di bawah kepemimpinan Kepala Seksi Operasional, dengan melakukan penjagaan objek wisata. Badan Penyelenggara Jaminan Produk Halal membentuk perwakilan di daerah, salah satunya dalam bentuk Satuan Tugas (Satgas) di bawah Kementerian Agama Kanwil Kepulauan Riau. Satgas yang berada di bawah Kementerian Agama Kanwil Kepulauan Riau berperan sebagai fasilitator penerbitan sertifikat halal untuk produk makanan minuman dalam pengembangan destinasi pariwisata halal di Pulau Penyengat. Peran yang dijalankan oleh LPPOM MUI dalam mendukung pengembangan destinasi pariwisata halal Pulau Penyengat dilihat dari keterlibatan LPPOM MUI dalam pemeriksaan kualitas kehalalan suatu produk. Stakeholders yang berperan sebagai fasilitator dalam pengembangan destinasi pariwisata halal di Pulau Penyengat menunjukkan keterlibatannya sesuai dengan tugas pokok dan fungsinya masing-masing. Dilihat dari stakeholders yang berperan sebagai fasilitator, sebagian besar merupakan bagian dari pemerintah atau sektor publik, walaupun ada juga yang berasal dari elemen komunitas karena menjadi kesatuan fungsi dengan salah satu stakeholders sektor publik. Stakeholders yang berperan sebagai fasilitator akan menyediakan fasilitas pendukung dan menfasilitasi proses pengembangan pariwisata halal sesuai dengan fungsinya masing-masing. Sebagaimana yang disebutkan bahwa peran sektor publik dalam manajemen destinasi wisata (Niekerk, 2014) adalah sebagai berikut: memimpin dan koordinasi; menciptakan dan memelihara lingkungan destinasi wisata yang sesuai; pemasaran dan promosi; identifikasi elemen-elemen destinasi wisata; perencanaan dan penelitian; kemitraan dan pembangunan tim; hubungan masyarakat; pengembangan produk; sektor publik sebagai pelanggan/pembeli; menciptakan jaringan untuk keterlibatan stakeholders. Lingkungan destinasi wisata yang sesuai untuk pengembangan pariwisata halal harus didukung oleh kesediaan infrastruktur pariwisata.

\section{Implementor}

Peran Dinas Kebudayaan dan Pariwisata Kota Tanjungpinang 
sebagai implementor dalam pengembangan destinasi pariwisata halal Pulau Penyengat dapat dilihat dari kegiatan promosi dan penyediaan fasilitas pendukung. Kegiatan promosi wisata halal banyak dilakukan melalui media digital seperti facebook dan instagram. Dinas Kebudayaan dan Pariwisata Kota Tanjungpinang tidak memanfaatkan website sebagai alat pemasaran wisata Pulau Penyengat. Hal ini dapat dilihat dengan kondisi website yang tidak dapat diakses. Padahal penelitian $\mathrm{Wu}$ (2018) menunjukkan kegunaan website pariwisata sebagai aspek penting dalam membentuk citra destinasi wisata yang baik, dimana website pariwisata dapat menyediakan informasi yang berlimpah, menunjukkan foto tempat wisata yang menarik, dan tentunya menjalankan fungsi penjualan. Pokdarwis Pulau Penyengat sebagai komunitas lokal pengembangan wisata melakukan upaya pemasaran melalui facebook, instagram dan youtube. Citra destinasi wisata halal unggulan Pulau Penyengat belum diangkat sebagai highlight dalam menarik wisatawan untuk datang berkunjung. Padahal pemasaran digital mempengaruhi industri pariwisata dengan dominan karena kemudahan akses ke informasi terkait penawaran terbaik yang tersedia bagi konsumen (Gupta, 2019). Pokdarwis juga melakukan kegiatan sosialisasi ke masyarakat mengenai nilai-nilai Sapta Pesona yang merupakan jabaran konsep Sadar Wisata yang terkait dengan dukungan dan peran masyarakat sebagai tuan rumah dalam upaya untuk menciptakan lingkungan dan suasana kondusif yang mampu mendorong tumbuh dan berkembangnya industri pariwisata, melalui perwujudan unsur aman, tertib, bersih, sejuk, indah, ramah dan unsur kenangan. Penduduk setempat di destinasi wisata memainkan peran penting untuk meningkatkan citra wisatawan Muslim dan citra destinasi wisata secara keseluruhan (Han, 2019). PHRI Tanjungpinang sebagai koordinator pengusaha hotel dan restoran yang ada di Tanjungpinang, memberikan masukan dan ide kepada pemerintah setempat mengenai standar halal yang diterapkan di hotel dan restoran. Masih minimnya hotel dan restoran di Tanjungpinang yang memiliki sertifikat halal menjadi tantangan tersendiri untuk pengembangan wisata halal ini. Begitu juga dengan restoran di Tanjungpinang yang masih minim jumlah dalam kepemilikan sertifikat halal. Razzaq, Hall, \& Prayag (2016) menyebutkan bahwa wisatawan Muslim cenderung memilih akomodasi Syariah yang memiliki atribut-atribut seperti ketersediaan makanan halal, kepantasan seragam staf hotel, tidak adanya gambar berkonten pornografi, tidak tersedia minuman beralkohol, informasi mesjid terdekat untuk pelaksanaan sholat Jumat, ruang pertemuan dengan fasilitas beribadah. Ketersediaan makanan halal di destinasi wisata memungkinkan wisatawan Muslim untuk menikmati kuliner khas setempat sesuai dengan keyakinan mereka dan tentunya juga akan memotivasi mereka untuk mengunjungi destinasi wisata tersebut (Battour, 2016).ASITA saat ini masih pada tahap mengidentifikasi pasar wisata halal untuk dikembangkan dan didistribusikan ke calon wisatawan dengan targetnya adalah wisatawan dari suku Melayu di Malaysia dan Singapura. ASITA belum menyediakan paket wisata halal Pulau Penyengat secara khusus. Karena Pulau Penyengat mengangkat 
wisata religi dan budayanya, maka paket wisata yang disediakan baru menawarkan hal tersebut. Belum optimalnya peran ASITA dikarenakan masih dalam tahap menciptakan paket wisata yang dapat menjangkau pasar wisatawan lebih luas (Muslim dan non Muslm) namun tetap memegang teguh norma agama dan norma budaya setempat. ASITA menilai bahwa atraksi wisata yang kini hadir di Pulau Penyengat masih kurang "menjual" (http://rri.co.id/post/berita/633187 /budaya_dan_wisata/asita_festival_pu lau_penyengat_belum_bisa_dijual.htm l). Agen perjalanan menargetkan kunjungan wisatawan Muslim dengan menyesuaikan elemen dalam paket wisata halal seperti ketersediaan makanan halal, rencana perjalanan yang dibangun berdasarkan waktu sholat, kunjungan ke masjid dan pemandu wisata Muslim (Battour, 2016).Dari perkumpulan pramuwisata Tanjungpinang, HPI Tanjungpinang menyampaikan masukan kepada pemerintah setempat mengenai kebutuhan wisatawan selama berwisata di Pulau Penyengat yang belum terakomodir, serta masukan mengenai pengembangan kapasitas SDM pramuwisata di Tanjungpinang. Peran HPI sangat penting dalam mengedukasi wisatawan yang berkunjung terutama mengenai etika berpakaian dan bersikap selama berkunjung di Pulau Penyengat.

\section{d. Akselerator}

Hasil wawancara dapat dilihat bahwa peran akademisi lokal dalam pengembangan pariwisata halal belum optimal. Akademisi di Tanjungpinang selama ini berkontribusi dalam bidang pariwisata secara umum melalui beberapa kegiatan, namun tidak dalam penyusunan kebijakan pengembangan pariwisata. UGM menjadi salah satu universitas yang berperan dalam pengembangan pariwisata di Pulau Penyengat melalui kegiatan Kuliah Kerja Nyata Pembelajaran Pemberdayaan Masyarakat (KKN-PPM) tahun 2018, dengan melaksanakan Deklarasi Warga Pulau Penyengat bertema "Penyengat Kampung Kite, Penyengat Warisan Kite" (https://scscel.kkn.ugm.ac.id/2018/12/17/ugmkkn-ppm-students-raise-the-tourismpotential-of-penyengat-island/).

Diharapkan dengan keberadaan perguruan tinggi akan memberikan kontribusi langsung dalam evaluasi program pembangunan daerah dan perencanaan pembangunan daerah yang bersinergi dengan masyarakat; dan secara tidak langsung dapat membantu memberikan pelatihanpelatihan dan sumbangan pemikiran dalam proses pengelolaan suatu destinasi (Magnadi, 2011). Media massa berperan sebagai perantara dalam penyampaian informais dari pemerintah kepada masyarakat mengenai penyelenggaraan pariwisata halal di Pulau Penyengat. Media massa menjadi mediator antara pariwisata dan masyarakat. Pilihan destinasi wisata bergantung pada informasi yang didapatkan dari media massaPembangunan citra yang baik dan menarik bagi destinasi wisata halal di Pulau Penyengat melalui media massa akan menjadi penggerak bagi ketertarikan calon wisatawan untuk berkunjung. Pengembangan pariwisata dan media massa mengacu pada semua kegiatan seperti pengembangan keterampilan, penyediaan lapangan kerja dan pemasaran produk pariwisata melalui berbagai saluran media massa sehingga wisatawan dapat mengetahui tentang potensi wisata yang dimiliki (Enemuo , 2015). 


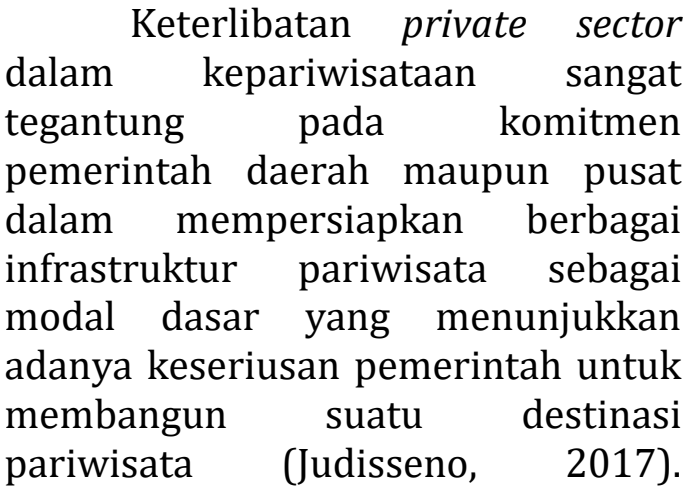

Keterlibatan Bank Indonesia, Pelindo 1 dan Al Ahmadi Enterprenuership Center, yang berasal dari kalangan swasta atau bisnis, dalam pengembangan destinasi pariwisata halal di Pulau Penyengat diwujudkan dalam bentuk kontribusi, baik berupa bantuan sponsor, dukungan infrastruktur, ide maupun gagasan. Stakeholders yang berperan sebagai akselerator ini memiliki kepedulian yang besar dalam pengembangan pariwisata halal di Pulau Penyengat, namun tidak memiliki kepentingan secara langsung dan pengaruh besar dalam kebijakan pengembangan tersebut. Begitu pun yang terjadi dengan stakeholders yang berasal dari elemen komunitas seperti Lembaga Adat Melayu (LAM) Provinsi Kepulauan Riau, Yayasan Indera Sakti, Yayasan Aksi Bangun Negeri. Djakfar (2017) menyebutkan bahwa Mahathir Mohammad pernah mengajukan tiga kiat memajukan wisata halal berdasarkan pengamatannya di negaranya sendiri, yaitu mengedepankan dan menjaga nilai-nilai Islami dan kearifan lokal; mengadopsi hal-hal yang baik dari sistem dan standar yang didominasi peradaban Barat; dan menjalankan konsep dan market-oriented. Komunitas fotografi terutama berperan besar dalam mempromosikan destinasi wisata halal Pulau Penyengat melalui hasil fotonya di laman media sosial. Keterlibatan komunitas fotografi juga dapat dilihat dalam peran serta komunitas sebagai peserta proses uji coba dan dokumentasi produk wisata Pulau Penyengat yang diselenggarakan tahun lalu. Begitu juga dengan komunitas blogger di Tanjungpinang yang terlibat dalam promosi pariwisata halal Pulau Penyengat. Komunitas blogger memberikan kontribusinya melalui tulisan-tulisan di blog yang berkiatan dengan Pulau Penyengat, misalnya mengenai penginapan di Pulau Penyengat, destinasi wisatanya, dan mengunggah foto-foto spot menarik di Pulau Penyengat. Berdasarkan hasil wawancara diketahui bahwa Pemerintah Daerah belum melibatkan komunitas blogger dalam upaya pengembangan destinasi pariwisata halal Pulau Penyengat.

\section{Hubungan Antar Stakeholders Di lihat dari Bentuk a.Individual Evaluations}

Hubungan yang terjadi antara individu stakeholders yang terlibat dalam pengembangan destinasi pariwisata halal Pulau Penyengat ditunjukkan melalui hubungan individu yang berasal dari organisasi yang berbeda, sebagai contoh hubungan antara Kepala Dinas Kebudayaan dan Pariwisata Kota Tanjungpinang, Kepala Bidang Destinasi Dinas Kebudayaan dan Pariwisata Kota Tanjungpinang dengan akademisi UMRAH. Dalam hubungan yang bersifat informal ini, terjadi komunikasi mengenai perkembangan pariwisata halal di Tanjungpinang, khususnya Pulau Penyengat. Kepedulian akademisi terhadap perkembangan pariwisata ditunjukkan dengan komunikasi dan hubungan baik yang terjaga dengan pihak pemerintah. Komunikasi yang dilakukan individu-individu stakeholders ini merupakan salah satu perwujudan untuk menjalin hubungan yang saling 
menguntungkan untuk stakeholders secara organisasi, dan tentunya mewujudkan tujuan bersama untuk pengembangan pariwisata halal. Selain meningkatkan kesejahteraan pribadi, hubungan interpersonal yang positif antara para stakeholders dalam kolaboratif dapat berkontribusi pada berbagai hasil bermanfaat lainnya. Secara umum, semakin baik hubungan antar individu dalam suatu kelompok, semakin besar potensi kolaboratif mereka dan semakin efektif kinerja kelompok mereka (Pero, 2007).

\section{b.Transfer Material Resources}

Waligo (2013) mengamati bahwa implementasi yang muncul dari pariwisata berkelanjutan didorong oleh kemitraan stakeholders, yang menyiratkan bahwa implementasi pariwisata berkelanjutan sebagian besar tergantung pada keterlibatan stakeholders yang efektif. Salah satu bentuk keterlibatan stakeholders dalam pengembangan destinasi pariwisata halal di Pulau Penyengat adalah dalam bentuk hubungan transaksi berupa transaksi bisnis yang di dalamnya terdapat barang yang ditukar, diperjualbelikan, ataupun dipinjamkan. Hubungan ini dapat terlihat dalam hubungan yang terjalin antara LPPOM MUI dengan Dinas Perindustrian dan Perdagangan Kota Tanjungpinang. Hubungan kerjasama di antara dua organisasi ini bertujuan untuk menerbitkan sertifikat halal gratis untuk pelaku UMKM yang dibiayai oleh APBD Kota Tanjungpinang. Dalam hal ini terjadi transfer barang berupa sertifikat halal dari LPPOM MUI kepada Pemerintah Kota Tanjungpinang melalui Dinas Perindustrian dan Perdagangan Kota Tanjungpinang untuk selanjutnya diberikan secara gratis kepada UMKM. Hubungan tersebut sesuai dengan teori yang dikemukakan oleh Galaskiewicz and Marsden (dalam Pratama, 2018) yang menyatakan jenis hubungan ini melibatkan transaksi bisnis berupa barang, yang di dalamnya terdapat kegiatan pertukaran, peminjaman dan pembelian sebuah produk atau barang.

\section{c.Transfer Non-Material}

Hubungan ini merupakan hubungan stakeholders dalam pengembangan destinasi pariwisata halal di Pulau Penyengat yang berwujud pertukaran informasi melalui komunikasi antar stakeholders. Pertukaran informasi dapat terjadi dengan komunikasi secara interaksi fisik maupun komunikasi melalui media. Bentuk hubungan ini terjadi di seluruh stakeholders yang terlibat dalam pengembangan destinasi pariwisata halal di Pulau Penyengat. Pertukaran informasi dijalin dengan cukup intens, walaupun koordinasi untuk menyatukan seluruh informasi dari stakeholders belum berjalan optimal. Semakin tinggi intensitas berinteraksi di antara satu individu dengan individu lain, maka informasi yang dipertukarkan semakin banyak pula (Hertanto \& Safitri dalam Bakti, 2020). Dinas Kebudayaan dan Pariwisata Kota Tanjungpinang merupakan pusat informasi dalam pengembangan destinasi pariwisata halal di Pulau Penyengat. Sebagai pusat informasi, sebagian besar pengetahuan dalam penyelenggaraan pariwisata halal berada di Dinas Kebudayaan dan Pariwisata Kota Tanjungpinang. Oleh karena itu, Dinas Kebudayaan dan Pariwisata Kota Tanjungpinang harus memiliki pola komunikasi efektif agar seluruh informasi mengenai wisata halal dapat diakses dan diterima oleh stakeholders yang terlibat. 


\section{Di lihat dari Interaction}

Interaksi merupakan sebuah hubungan yang melibatkan interaksi fisik di antara aktor pada waktu dan tempat yang sama, seperti pertemuan, percakapan, dan lain-lain. Hubungan interaksi dalam pengembangan destinasi pariwisata halal di Pulau Penyengat dapat dilihat dari beberapa pertemuan yang dilakukan oleh stakeholders secara formal maupun informal. Proses interaksi ini sangat penting untuk mengkomunikasikan masalah yang menghambat dan gagasan baru untuk mendukung pengembangan destinasi pariwisata halal. Stakeholders sering hidup secara berdampingan tetapi tidak berinteraksi satu sama lain, dan kurangnya keterlibatan stakeholders dapat merusak upaya pengembangan pariwisata (Nyaupane, 2009). Komunikasi menjadi elemen penting dalam proses interaksi stakeholders pengembangan destinasi pariwisata halal Pulau Penyengat. Dalam proses interaksi kualitas komunikasi harus terus diperhatikan agar informasi yang disampaikan dapat diterima dengan baik. Interaksi di antara stakeholders yang terlibat akan memunculkan ide, gagasan dan masukan untuk pengembangan pariwisata. Hal ini terjadi akibat dari pertukaran informasi antar stakeholders sehingga hasil olahan informasi dapat berkembang menjadi ide baru untuk meningkatkan kualitas proses pengembangan pariwisata halal.

\section{Di lihat dari Movement}

Hubungan yang berupa bentuk perpindahan stakeholders ini dapat dilihat dari hubungan perpindahan kewenangan penerbitan sertifikat halal berdasarkan Undang Undang Nomor 33 Tahun 2014 tentang Jaminan Produk Halal yang sebelumnya ada di LPPOM MUI Provinsi Kepulauan Riau, namun sekarang kewenangannya berada di Badan Penyelenggara Jaminan Produk Halal (BPJPH), salah satunya dalam bentuk Satuan Tugas (Satgas) di bawah Kementerian Agama Kanwil Kepulauan Riau. Dengan perpindahan kewenangan dari LPPOM MUI kepada BPJPJ maka koordinasi Disperindag untuk pengurusan pemberkasan syarat sertifikat halal juga berpindah ke Satgas BPJPH di bawah Kementerian Agama Kanwil Kepulauan Riau. Pejabat pemerintah harus memiliki kompetensi berbasis pengetahuan untuk merencanakan dan mengimplementasikan strategi, dan berdasarkan keahlian mereka, memiliki pengaruh besar pada pengambilan keputusan politik (Komppula, 2016). Kepercayaan juga menjadi kunci dalam hubungan yang baru ini. Perpindahan kewenangan tentunya akan menciptakan sebuah hubungan baru di antara dua stakeholders. Penelitian Waayers (2012) menegaskan bahwa keberhasilan kolaborasi bergantung pada membangun kemitraan dan kepercayaan, mengakui saling ketergantungan, menghasilkan visi dan tujuan bersama dan komitmen di antara para stakeholders dalam proses terstruktur.

\section{Di lihat dari Formal Roles}

Hubungan ini juga dapat dilihat pada kewenangan BPJPH melalui Satgas di Kementerian Agama Kanwil Kepulauan Riau mendesak para pelaku usaha kuliner, baik itu pelaku UMKM maupun yang terwakili dalam PHRI dan Asosiasi Kuliner Rumahan, untuk memiliki sertifikat halal untuk produk mereka. Di destinasi wisata, kekuasaan dapat diberikan untuk mengorganisir para stakeholders serta menengahi perselisihan atau mencegah potensi konflik (Beritelli \& Laesser, 2011). Kekuatan stakeholders ditentukan oleh seberapa banyak 
sumber daya yang dimiliki stakeholders daripada sejauh mana stakeholders memiliki jaringan sendiri (Tiew et al., 2015). Perspektif ketergantungan sumber daya menunjukkan bahwa stakeholders harus mengakses 'sumber' kekuasaan untuk mengerahkan kekuasaan (Tiew et al., 2015). Berdasarkan Undang Undang Nomor 33 Tahun 2014 tentang Jaminan Produk Halal disebutkan bahwa produk yang masuk, beredar, dan diperdagangkan di wilayah Indonesia wajib bersertifikat halal. Dengan sifat kepemilikan sertifikat halal yang wajib bagi seluruh pemilik usaha kuliner, maka pemerintah melalui lembaga resmi yang ditunjuk berhak memberikan tekanan bagi seluruh kelompok sasaran kebijakan tersebut untuk memenuhi kewajiban tersebut.

\section{Di lihat dari Kinship}

Kinerja destinasi wisata tergantung pada hubungan antara berbagai pelaku komponen ini, tidak hanya pada karakteristik masingmasing (Presenza, 2010). Hubungan kinship merupakan bentuk hubungan kekeluargaan di antara para stakeholders yang terlibat dalam pengembangan destinasi pariwisata halal Pulau Penyengat. Driscoll dan Starik (dalam Jamal, 2009) memperluas model identifikasi dan arti penting stakeholders yang dikembangkan oleh Mitchell et al. dengan merekonseptualisasi atribut pemangku kepentingan kekuasaan, legitimasi dan urgensi, serta dengan mengembangkan atribut pemangku kepentingan keempat: kedekatan. Hubungan kekeluargaan dapat dilihat dalam pola hubungan yang terjadi di antara pengurus Pokdarwis Pulau Penyengat dan pengurus Yayasan Indera Sakti. Yayasan Indera Sakti berbentuk yayasan keluarga dengan pengurus yang merupakan anggota keluarga/kerabat. Raja Malik Hafrizal juga tercatat dalam struktur organisasi Pokdarwis Pulau Penyengat dan berkedudukan sebagai Penasehat. Dari penjelasan tersebut dapat dilihat bahwa masih terdapat hubungan kekeluargaan di antara kepengurusan Pokdarwis Pulau Penyengat dengan Yayasan Indera Sakti. Hubungan kekeluargaan seperti ini tentunya memiliki dampak positif dan juga negatif. Hubungan kekeluargaan tersebut dapat meningkatkan hubungan kerjasama di antara kedua organisasi tersebut, namun juga rawan konflik kepentingan.

\section{Aktivitas \\ Di lihat dari Kerjasama}

Proses kerjasama terjadi ketika di antara individu atau kelompok menyadari adanya kepentingan dan ancaman yang sama. Kerjasama antar stakeholders yang terlibat dalam pengembangan destinasi pariwisata halal Pulau Penyengat sebagian besar merupakan hubungan kerjasama atas dasar tupoksi, aturan kelembagaan, serta kesamaan visi dan misi suatu lembaga, instansi dan kelompok masyarakat. Junaid (2019) berpandangan bahwa kesuksesan pemasaran destinasi wisata tidak terlepas dari bagaimana suatu stakeholders menjalankan kolaborasi atau bekerja secara bersama mencapai tujuan yang diharapkan. Kerjasama antara Dinas Kebudayaan dan Pariwisata Kota Tanjungpinang dengan Pokdarwis Pulau Penyengat melahirkan delapan paket wisata Pulau Penyengat, yang tentunya menjadi alat promosi pariwisata halal Pulau Penyengat kepada wisatawan, karena dalam paket wisata tersebut mengandung konten wisata religi yang mengajak wisatawan merasakan langsung kehidupan Muslim setempat dengan adat budaya yang 
menyertainya. Kinerja destinasi wisata tergantung pada hubungan antara berbagai pelaku komponen ini, tidak hanya pada karakteristik masing-masing (Presenza, 2010).

\section{Komunikasi dan Koordinas}

Hubungan komunikasi antara stakeholders terjadi pada seluruh kegiatan pengembangan destinasi pariwisata halal Pulau Penyengat. Walaupun kegiatan pengembangan destinasi pariwisata halal Pulau Penyengat masih dalam tahap perencanaan, namun komunikasi terus dilakukan dengan stakeholders yang terlibat. Menurut Tubbs dan Moss (dalam Bakti, 2020), komunikasi dikatakan efektif apabila menimbulkan pengertian, kesenangan, pengaruh pada sikap, hubungan yang baik, dan tindakan. Komunikasi yang terjalin di antara para stakeholders pengembangan destinasi pariwisata halal Pulau Penyengat berdampak pada hubungan kerjasama yang baik dalam melaksanakan fungsinya masingmasing. Dari sejumlah hubungan komunikasi terjalin, ternyata hubungan komunikasi Dinas Kebudayaan dan Pariwisata Kota Tanjungpinang dengan beberapa stakeholders masih cukup minim, seperti pihak akademisi, LPPOM MUI, komunitas blogger, komunitas fotografi, Yayasan Indera Sakti, Yayasan Aksi Bangun Negeri. Komunikasi stakeholders yang disebut sebelumnya ini kurang optimal dalam hubungannya dengan pihak leading sector, namun mereka tetap melakukan komunikasi dengan stakeholders lainnya untuk mendukung pariwisata halal Pulau Penyengat. Penelitian Holladay (2017) menunjukkan bahwa kekuatan jaringan hubungan di antara organisasi-organisasi stakeholders agak lemah disebabkan oleh meskipun organisasi stakeholders dapat berkomunikasi dan berkoordinasi di seluruh jaringan, mereka mungkin tidak melakukannya.

Belum ada koordinasi yang membentuk komitmen bersama, sinergitas kegiatan dan penyatuan persepsi antara seluruh stakeholders untuk pengembangan pariwisata halal Pulau Penyengat. Koordinasi di antara instansi pemerintah masih kurang optimal dikarenakan masih adanya egosentris kelembagaan dan perbedaan pemahaman antar lembaga. Salah satu tantangan dalam koordinasi adalah bahwa para stakeholders memiliki tujuan yang bertentangan satu sama lain (Olovsson, 2012). Meskipun para stakeholders memiliki kegiatan dan tujuan untuk memaksimalkan keuntungan mereka sendiri, konsumen (pengunjung, investor, penduduk) menilai sebuah kota sebagai satu entitas, dan akan menilai kota tersebut sesuai dengan seberapa baik para stakeholders dapat menyediakan apa yang menjadi kebutuhan individu. Koordinasi dalam pengembangan destinasi pariwisata halal Pulau Penyengat belum berjalan secara maksimal. Unsur-unsur komunitas yang menjadi penggerak pariwisata di level bawah justru berinisiatif menciptakan agenda atau kegiatan sendiri-sendiri untuk mendukung pelaksanaan wisata halal di Pulau Penyengat. Dalam koordinasi, organisasi pariwisata yang otonom menyelaraskan kegiatan, mensponsori acara tertentu, atau memberikan layanan yang ditargetkan untuk mencapai tujuan yang sesuai. Dalam kolaborasi, para pihak bekerja secara kolektif melalui strategi bersama. Dalam jaringan strategis, semua organisasi pariwisata yang terlibat dalam jaringan memiliki visi bersama dan 
mengambil orientasi sistem untuk mencapai tujuan kelompok melalui strategi yang konsisten dan upaya bersama (Wang, 2007).

\section{Faktor Pendukung 1.Nilai}

Nilai individual diwujudkan melalui peran kepemimpinan Walikota sebagai penggerak dalam pengembangan destinasi pariwisata halal di Kota Tanjungpinang, khususnya Pulau Penyengat. Kepemimpinan yang baik sangat penting untuk koordinasi yang sukses (Olovsson, 2012). Nilai organisasi yang dikembangkan pada hubungan kerjasama stakeholders dalam pengembangan destinasi pariwisata halal Pulau Penyengat dicerminkan dalam nilai organisasi masing-masing institusi yang dapat mendukung pengembangan destinasi pariwisata halal Pulau Penyengat. Secara keseluruhan, pariwisata yang kuat dapat mendorong pertumbuhan ekonomi suatu negara seperti halnya pariwisata halal. Sebagai contoh, Ghani (dalam Rasul, 2019) menyatakan bahwa pertumbuhan ekonomi Malaysia telah secara signifikan terangkat oleh industri pariwisata halal. Hal ini sejalan dengan nilai kepentingan umum dengan sasaran kesejahteraan masyarakat terutama di daerah sekitar objek wisata yang dikembangkan.

Nilai legalitas yang mendukung aspek kerjasama stakeholders didasari atas Peraturan Daerah Kota Tanjungpinang Nomor 6 Tahun 2010 tentang Usaha Pariwisata Kota Tanjungpinang dan Peraturan Daerah Kota Tanjungpinang Nomor 8 Tahun 2018 tentang Pengelolaan Wisata Budaya Pulau Penyengat. Pariwisata yang berkelanjutan harus diupayakan melalui adopsi kebijakan pariwisata, mengingat pentingnya sektor publik (di tingkat negara bagian, regional dan kota) dalam pengembangan pariwisata (Martini, 2015). Nilai profesionalitas mencerminkan kemampuan dan komitmen individu yang melaksanakan kebijakan terkait pada pengembangan destinasi pariwisata halal Pulau Penyengat. Pejabat pemerintah harus memiliki kompetensi berbasis pengetahuan untuk merencanakan dan mengimplementasikan strategi, dan berdasarkan keahlian mereka, mereka mungkin sering memiliki pengaruh besar pada pengambilan keputusan politik (Komppula, 2016).

\section{Komunikasi}

Komunikasi yang efektif menjadi salah satu pendukung dalam hubungan kerjasama di antara stakeholders yang terlibat dalam pengembangan destinasi pariwisata halal di Pulau Penyengat. Komunikasi dalam kegiatan pariwisata sangat penting karena dengan komunikasi dapat membangun pengetahuan, perasaan, keinginan, dan keikutsertaan orang untuk mengunjungi objek wisata di suatu daerah. Komunikasi yang efektif dapat membangun hubungan baik, menyelesaikan perbedaan pendapat, dan dapat mengatasi konflik (Hijrah, 2017). Hubungan komunikasi dalam pengembangan destinasi pariwisata halal di Pulau Penyengat terjalin oleh semua stakeholders yang terlibat. Seluruh stakeholders secara aktif melakukan komunikasi terutama antara stakeholders yang memiliki hubungan kerjasama dan pelaksanaan koordinasi. Membangun komunikasi dapat mengakibatkan terpenuhinya kebutuhan emosional, intelektual, dan hubungan yang harmonis dengan orang lain (Mudjiono, 2012). 


\section{Faktor Penghambat 1.Kepercayaan}

Faktor kepercayaan menjadi salah satu penghambat dalam pengembangan destinasi pariwisata halal di Pulau Penyengat. Hubungan antara beberapa stakeholders yang terjalin masih memiliki peluang timbulnya rasa kurang percaya di antara stakeholders, walaupun stakeholders sudah menjalankan tugas dan peran sesuai dengan fungsinya. Pada pengembangan pariwisata halal Pulau Penyengat, kurangnya kepercayaan pada hubungan kerjasama antara stakeholders timbul akibat tidak adanya koordinasi, sinergi serta komando dari leading sector untuk penyelenggaraan pariwisata halal di kalangan komunitas penggiat wisata. Padahal strategi destinasi pariwisata berkelanjutan membutuhkan praktik membangun konsensus kolaboratif dan inklusif, dimana dipertimbangkan dimensi kepercayaan (Presenza, 2010). Kepercayaan dipupuk oleh komitmen, dengan berbagi informasi dan keahlian serta dengan mengkonsolidasikan hubungan antara para pihak.

\section{Kebijakan}

Pengembangan destinasi
pariwisata halal di
Tanjungpinang, khususnya Pulau Penyengat, belum didukung oleh regulasi yang mengatur penyelenggaraan wisata halal ini. Absennya keberadaan regulasi mengenai pariwisata halal di level nasional dan di tingkat lokal menjadi hambatan bagi pelaku industri pariwisata untuk menerapkan konsep pariwisata ini. Hal tersebut juga menjadi salah satu penyebab belum optimalnya hubungan kerjasama di antara para stakeholders yang terlibat dalam pengembangan pariwisata halal Pulau Penyengat. Judissseno (2017) menyebutkan bahwa pemerintah harus menetapkan kerangka kebijakan pembangunan pariwisata agar pihak swasta memiliki pijakan dan landasan jika ingin berpartisipasi dalam pembangunan pariwisata. Keterlibatan pemerintah lebih pada aspek pembuatan kebijakan yang mendorong pertumbuhan dan semaksimal mungkin menghapus berbagai hambatan birokrasi. Melihat pernyataan tersebut, dapat dilihat bahwa dalam pengembangan destinasi pariwisata halal di Pulau Penyengat, pihak pemerintah belum menjalankan perannya dalam pembuatan kebijakan untuk pengembangan destinasi wisata halal di Pulau Penyengat.

\section{KESIMPULAN}

Dari hasil penelitian dapat disimpulkan bahwa berdasarkan konsep pentahelix, stakeholders yang terlibat dalam pengembangan destinasi pariwisata halal di Pulau Penyengat terdiri dari Akademisi, Bisnis, Pemerintah, Komunitas dan Media Massa. Identifikasi stakeholders berdasarkan kategori stakeholders, terdiri dari Stakeholders Primer, Stakeholders Kunci, dan Stakeholders Sekunder. Peran stakeholders yang terlibat dalam pengembangan destinasi pariwisata halal di Pulau Penyengat ada Policy creator, Koordinator, Fasilitator, Implementor dan Akselerator. Dari sekian peran, peran policy creator belum optimal dibuktikan dengan belum diterbitkannya peraturan mengenai pariwisata halal di Kota Tanjungpinang. Peran koordinator juga belum optimal karena tidak adanya koordinasi seluruh stakeholders oleh Disbudpar. 
Peran PHRI dan ASITA juga belum optimal karena masih mencari konsep terbaik penerapan pariwisata halal untuk penginapan dan paket wisata.Hubungan antara stakeholders yang terlibat dalam pengembangan destinasi pariwisata halal di Pulau Penyengat dilihat dari bentuk dan aktivitasnya. Berdasarkan bentuknya, hubungan antar stakeholders ditemukan dalam tujuh bentuk yaitu individual evaluations, transfer material resources, transfer nonmaterial, interaction, movement, formal roles, dan kinship. Sedangkan berdasarkan aktivitasnya, hubungan stakeholders ditemukan dalam tiga jenis yaitu kerjasama, komunikasi dan koordinasi.Faktor pendukung dalam pengembangan destinasi pariwisata halal di Pulau Penyengat antara lain nilai individual dalam peran Walikota sebagai penggerak kegiatan pengembangan destinasi pariwisata halal; nilai profesionalitas ditunjukkan oleh kemampuan stakeholders menjalankan perannya sesuai tugas dan fungsinya; nilai kepentingan umum untuk kesejahteraan masyarakat; dan komunikasi terjalin pada seluruh hubungan antar stakeholders yang terlibat. Faktor penghambat antara lain belum adanya kebijakan mengenai pariwisata halal; akibat belum adanya koordinasi secara menyeluruh dari leading sector, muncul sikap kurang percaya di kalangan penggiat wisata; belum adanya badan khusus yang mengelola wisata di Pulau Penyengat; fasilitas pendukung pariwisata halal belum tersedia secara optimal; promosi pariwisata halal melalui saluran digital belum dilakukan secara maksimal.

Rekomendasi yang disampaikan adalah Pemerintah Daerah sebaiknya segera membuat regulasi pengembangan pariwisata halal, pembentukan badan khusus untuk pengelolaan wisata Pulau Penyengat harus segera ditindaklanjuti, meningkatkan intensitas dan kualitas komunikasi serta koordinasi antar stakeholders, peningkatan peran akademisi lokal dan komunitas yang fokus pada pelestarian nilai budaya dan adat istiadat Melayu, peningkatan kualitas fasilitas pendukung pariwisata halal, peningkatan promosi pariwisata halal melalui saluran digital.

\section{REFERENSI}

Alonso, A. D., \& Nyanjom, J. (2015). Current Issues in Tourism Local stakeholders, role and tourism development. 3500(December). https://doi.org/10.1080/13683 500.2015.1078782

Amalyah, R., Hakim, L., Administrasi, F. I., \& Brawijaya, U. (2016). Peran stakeholder pariwisata dalam pengembangan pulau samalona sebagai destinasi wisata bahari. 37(1), 158-163.

Aribowo, H., Wirapraja, A., \& Putra, Y. D. (2018). Implementasi Kolaborasi Model Pentahelix Dalam Rangka Mengembangkan Potensi Pariwisata Di Jawa Timur Serta Meningkatkan Perekonomian Domestik. Jurnal Mebis (Manajemen Dan Bisnis), 3(1), 31-38. https://doi.org/10.33005/mebis .v3i1.21

Battour, M., \& Ismail, M. N. (2016). Halal tourism: Concepts, practises, challenges and future. Tourism Management Perspectives, 19, 150-154. https://doi.org/10.1016/j.tmp.2 015.12 .008

Beritelli, P. (2011). Cooperation among prominent actors in a tourist destination. Annals of Tourism Research, 38(2), 607- 
629.

https://doi.org/10.1016/j.annals .2010.11.015

Bregoli, I., \& Del Chiappa, G. (2013). Coordinating relationships among destination stakeholders: Evidence from edinburgh (UK). Tourism Analysis, 18(2), 145155.

https://doi.org/10.3727/10835

4213X13645733247657

Djakfar, M. (2017). Pariwisata Halal Perspektif Multidimensi Peta Jalan Menuju Pengembangan Akademik \& Industri Halal di Indonesia. Malang: UIN-Maliki Press.

Enemuo, O. B., \& Amaechi, B. (2015). The Role of Mass Media in Tourism Development in Abia State. Journal of Tourism, Hospitality and Sports, 11(2013), 44-50. Retrieved from http://www.iiste.org/Journals/i ndex.php/JTHS/article/view/24 693/25295

Galvão, A., Mascarenhas, C., Gouveia Rodrigues, R., Marques, C. S., \& Leal, C. T. (2017). A quadruple helix model of entrepreneurship, innovation and stages of economic development. Review of International Business and Strategy, 27(2), 261-282. https://doi.org/10.1108/RIBS01-2017-0003

Handayani, F., \& Warsono, H. (2017). Analisis Peran Stakeholders Dalam Pengembangan Objek Wisata Pantai Karang Jahe Di Kabupaten Rembang. Journal of Public Policy and Management UNDIP, 06, 1-13. Retrieved from https://media.neliti.com/media/ publications/183052-IDanalisis-peran-stakeholdersdalam-pengem.pdf

Harto, S., \& Penyengat, P. (2019). MODEL KOMUNIKASI PEMERINTAHAN KOTA TANJUNG
PINANG. 21-34.

Henderson, J. C. (2016). Halal food, certification and halal tourism: Insights from Malaysia and Singapore. Tourism Management Perspectives, 19, 160-164. https://doi.org/10.1016/j.tmp.2 015.12.006

Jeaheng, Y., Al-Ansi, A., \& Han, H. (2019). Halal-friendly hotels: impact of halal-friendly attributes on guest purchase behaviors in the Thailand hotel industry. Journal of Travel and Tourism Marketing, 36(6), 729746.

https://doi.org/10.1080/10548 408.2019.1631940

Jesus, C., \& Franco, M. (2016). Cooperation networks in tourism: A study of hotels and rural tourism establishments in an inland region of Portugal. Journal of Hospitality and Tourism Management, 29, 165175.

https://doi.org/10.1016/j.jhtm.2 016.07.005

Judisseno, R. K. (2017). Aktivitas dan Kompleksitas Kepariwisataan Suatu Tinjauan Tentang Kebijakan Pengembangan Kepariwisataan. Jakarta: PT Gramedia Pustaka Utama.

Komppula, R. (2016). The role of different stakeholders in destination development. Tourism Review, 71(1), 67-76. https://doi.org/10.1108/TR-062015-0030

Longart, P., Wickens, E., Ocaña, W., \& Llugsha, V. (2017). A stakeholder analysis of a service learning project for tourism development in An Ecuadorian Rural Community. Journal of Hospitality, Leisure, Sport and Tourism Education, 20(April), 87-100. https://doi.org/10.1016/j.jhlste. 
2017.04.002

Muhyi, H. A., \& Chan, A. (2017). The Penta Helix Collaboration Model in Developing Centers of Flagship Industry in Bandung City. 6(1), 412-417.

Nurfatriani, F., Darusman, D., Nurrochmat, D. R., Yustika, A. E., Penelitian, P., \& Iklim, P. (2015). (Stakeholder Analysis in Green Fiscal Policy Transformation ). 105-124.

Oktavia, S., \& . S. (2015). Hubungan Peran Stakeholders Dengan Partisipasi Masyarakat Dalam Program Agropolitan Desa Karacak Kecamatan Leuwiliang Kabupaten Bogor. Sodality: Jurnal Sosiologi Pedesaan, 1(3), 231-246.

https://doi.org/10.22500/sodali ty.v1i3.9407

Persari, D., Heriyanto, M., \& Yuliani, F. (2018). Implementasi Strategi Pengembangan Kepariwisataan. JIANA (Jurnal Ilmu Administrasi Negara), 15(1), 104-109.

Pjerotic, L. (2017). Stakeholder cooperation in implementation of the sustainable development concept: Montenegrin tourist destinations. Journal of International Studies, 10(2), 148157. https://doi.org/10.14254/20718330.2017/10-2/11

Pratama, R. (2018). Analisis Pemetaan Jejaring Stakeholder Pariwisata di kota Batu Dengan Menggunakan Metode Social Network Analysis (SNA). Jurnal Administrasi Bisnis (JAB), 54(1), 179-188.

Pratiwi, S. R., Dida, S., \& Sjafirah, N. A. (2018). Strategi Komunikasi dalam Membangun Awareness Wisata Halal di Kota Bandung. Jurnal Kajian Komunikasi, 6(1), 78.

https://doi.org/10.24198/jkk.v6

\section{i1.12985}

Razzaq, S., Hall, C. M., \& Prayag, G. (2016). The capacity of New Zealand to accommodate the halal tourism market - Or not. Tourism Management Perspectives, 18, 92-97. https://doi.org/10.1016/j.tmp.2 016.01.008

Samori, Z., Md Salleh, N. Z., \& Khalid, M. M. (2016). Current trends on Halal tourism: Cases on selected Asian countries. Tourism Management Perspectives, 19, 131-136.

https://doi.org/10.1016/j.tmp.2 015.12.011

Sugiyono. (2011). Metode Penelitian Kuantitatif, Kualitatif dan $R \& D$. Bandung: Penerbit Alfabeta.

Waligo, V. M., Clarke, J., \& Hawkins, R. (2013). Implementing sustainable tourism: A multistakeholder involvement management framework. Tourism Management, 36, 342353.

https://doi.org/10.1016/j.tourm an.2012.10.008

Widodo, M. L., Soekmadi, R., \& Arifin, H. S. (2018). Analisis Stakeholders Dalam Pengembangan Ekowisata Di Taman Nasional Betung Kerihun Kabupaten Kapuas Hulu. Jurnal Pengelolaan Sumberdaya Alam Dan Lingkungan Uournal of Natural Resources and Environmental Management), 8(1), 55-61. https://doi.org/10.29244/jpsl.8. 1.55-61

Yulianty, M., Teknik, M., Kota, P., Sarjana, P. P., \& Diponegoro, U. (2005). Partisipasi masyarakat dalam memelihara benda cagar budaya di pulau penyengat sebagai upaya pelestarian warisan budaya melayu.

Yuniningsih, T. (2018). Ringkasan 
Disertasi "Analisis Jaringan Aktor dalam Implementasi Kebijakan Pengembangan Pariwisata Kota Semarang."

Yuniningsih, T. \& S. S. (2018). Model Kemitraan Dalam Kebijakan Pengembangan Pariwisata Di Kota Tanjung Pinang Provinsi Kepulauan Riau.

\section{Dokumen}

Desain Strategis dan Rencana Aksi (DSRA) Pengembangan Destinasi Pariwisata Halal Kepulauan Riau tahun 2018-2019

Mastercard-CrescentRating Global Muslim Travel Index 2019

Undang Undang Nomor 33 Tahun 2014 tentang Jaminan Produk Halal

\section{Website}

http://www.kemenpar.go.id/post/sia ran-pers-indonesia-ditetapkansebagai-destinasi-wisata-halalterbaik-dunia-2019

http://www.halalmui.org/mui14/ind ex.php/main/detil page/59/25 $\underline{070}$

http://indonesia.crossborder.co.id/p ulau-penyengat-jadi-pilotproject-wisata-halal/

(https://www.republika.co.id/ berita/dunia-islam/islamnusantara/19/03/08/po1lou 458-permen-pariwisata-halalditargetkan-rampung-tahunini).

(https://www.indonesiatravel.news/ pariwisata/pulau-penyengatjadi-pilot-project-wisatahalal//).

https://www.hariankepri.com/hanya -60restoran-bakery-dan-cakeyang-bersertifikat-halal-ditanjungpinang/

(http://rri.co.id/post/berita/633187 /budaya dan wisata/asita festi val pulau penyengat belum bis a dijual.html). https://scscel.kkn.ugm.ac.id/2018/12/17 Lugm-kkn-ppm-students-raisethe-tourism-potential-ofpenyengat-island/ 